\title{
Factors That Affect Financial Performance of Micro and Small Business Enterprises in Dambi Dollo Town, Oromia, Ethiopia
}

\author{
Zewdu Eskezia Gelaye \\ College of Business and Economics, Department of Accounting and Finance, \\ Dembi Dollo University, Dembi Dollo Ethiopia
}

\begin{abstract}
It is recorded that most of the business bodies in Ethiopia are micro and small which have been an instrumental component in GDP and core for work opportunities. Even though the identification of the important roles that micro and small enterprises play in the country, their evolution is mostly bounded by a number of factors, such as the existence of rigid laws, shortage of infrastructures, financing problems etc that frustrate the growth of the sector as reviewed from the previous researchers. The main objective of the study was to determine the factors that affect financial performance of micro and small business enterprises in Dembi dollo town administration. To achieve this objective the necessary data was collected from micro and small business enterprise owners by using questionnaires. The study employed a mixed research approach i.e. both quantitative and qualitative research approaches. Stratified random sampling technique was used to select proportional number of samples from the target population of the study. The researcher used both descriptive and multiple regression analysis methods to analyze the raw data which was obtained from the respondents. The finding of the study shows that problems related with shortage of infrastructures, lack of human resources knowledge and skill, bureaucracy in company registration and getting a license, instability in tax policy and high tax rate have a negative significant effect on financial performance of small business enterprises in Dembi dollo town administration. On the other hand; nonexistence of government policy related problems such as; regulatory laws, labor laws and reporting laws positively contributes to the performance of micro and small business enterprises in the town. Based on the findings of the study the researcher recommends that the government and other concerned bodies for the development and performance of micro and small business enterprises in collaboration with the enterprise owners should alleviate the problems related with infrastructures, human resources knowledge and skill and government policies in order to achieve higher performance of small business enterprises in the town.
\end{abstract}

Keywords: micro and small enterprises, financial performance, infrastructures, knowledge, skill, financing, government policies

DOI: $10.7176 /$ RJFA/11-1-01

Publication date: January $31^{\text {st }} 2020$

\section{Introduction}

\subsection{Background of the Study}

Micro and Small business enterprises are vital and of paramount importance in the development of any country especially for a developing country like Ethiopia. They play multifaceted role such as boosting competition, innovation, as well as development of human capital and creation of a financial system.

Micro and Small businesses highly encourage the growth and development of any economy; by creating jobs, increases competition, generating income and innovation, opening possibilities for business ventures and etc. (de Kok et al., 2011). The presence of micro and small businesses in any economy in large quantity provides a basis for reviewing various factors related to their operations. In terms of increasing the importance of micro and small business for the growth and development of world economy, financial performance of micro and small businesses imposes itself as a relevant and important research area. Furthermore, the high failure rate, such as mortality of small businesses, increases the need towards overcoming issues pertinent to financial performance of micro and small business enterprises.

The significance of finances has been viewed as a critical element for financial performance of micro and small business enterprises; Limit to financial hinder growth and development of these firms (Levy, 2015). According to (Saito \& Villanueva, 2000) smaller enterprises face higher transaction costs than larger enterprises in obtaining credit. Lack of proper management experience and the application of poor accounting practices are also major factors that deter financial performance of small enterprises and it hinders the ability to raise finance. Information asymmetries related with lending to small scale business borrowers have restricted the flow of finance to smaller enterprises. In spite of these claims, as (Liedholm, Macpherson \& Chuta, 2007) a large number of micro and small enterprises fail because of non-financial reasons. According to (Tushabonwe Kazooba, 2006) poor record keeping and lack of basic business management experience and skills are major factors to the failure of micro and small business enterprises.

Researchers have also acknowledged shortage of access to external finance and weak capital base, lack of experience in the field of the business, particularly lack of technical knowledge, inadequate managerial skills, lack 
of planning and lack of market research are causes of small businesses failure (Van Stel \& Store, 2004).

Research studies have shown that the factors including: easy access to business information, access to finance, the existence of managerial experience and access to infrastructures should have been improved in order to improve the performance of micro and small business enterprises performance. The studies also show that the firms can improve their production capacity and can also perform well if government policies remain stable because frequent change in tax policies, Rigid government policies, Improper inspection methods of government regarding final product of small business enterprises regulatory issues etc. have made the entrepreneur unhappy regarding their own industries and this had affected the enterprises performance. Even though government has provided good policies for micro and small business enterprises performance and development but due to unstable government policies and frequent changes in taxation has hampered performance of the enterprises.

Improving the quality of human resources is highly needed, especially in the field of human resource competencies such as knowledge, skill, ability and attitude to entrepreneurship. Human resources development is advantageous not only for micro and small business owners but also for improving the livelihood of workers (Purwidianti, 2015). Entrepreneurship and productivity must be supported with the development of technology in order to strengthen the quality of human resource. On the other hand, the use of technology is increasingly important since most of the production process in small enterprises is still carried out in labor-intensive. Somehow this indicates the limited mastery of science and technology and marketing skills by small enterprise human resources.. Besides, the improvement of human resources is indispensable considering the development of micro and small business enterprises cannot be separated from the role of cooperative association (Laban \& Sirine, 2014) which is always providing capital, providing technical services and facilitating business networking in addition to raw material procurement and marketing for micro and small enterprises products.

In November 1997, the Ethiopian Ministry of Trade and Industry issued the "Micro and Small Enterprises Development Strategy", which enlightens a systematic approach to overcome the problems and promote the performance and growth of small and medium enterprises. Sequel to the publication of small and medium enterprises development strategic document, the government of Ethiopia set up Federal Micro and Small Enterprise Development Agency. The regional states also developed small and medium enterprises promotion strategies based on their context and in consistent with the federal small and medium enterprises so that the states structured Regional Micro and Small Enterprises Development Agencies to facilitate implementation of the strategies.

Although micro and small business enterprises have been recognized as a major today's source of employment and income in a growing number of developing countries, yet relatively little is known and emphasized about the characteristics and performance of these enterprises specific to the chosen study area in the present study. Study by (Belay, 2000) shows that $98 \%$ of business firms are micro and small enterprises and from which small enterprises denote $65 \%$ of all businesses. The fact that the majority of enterprises are micro and small indicates that established enterprises find it difficult to grow to the next stages of middle and large scale industries. Although the small and medium enterprises sector takes large proportion in the industrial sector, it contributes only $3.4 \%$ of the GDP, (Gebrehiwot G., 2006). Therefore, small and medium enterprises get difficult to grow at their full potential and hence contribute less to the national economy due to the existence of enormous business constraints in the sector.

According to the study by (Wolday\& Gebrehiowot, 2004) the leading factors affecting to the growth and performance of micro and small business enterprises are lack of access to finance, market, business services and working premises. Thus, critical assessment of the association between growth and constraints of enterprises is needed in order to get the contributions of their growth to the national economy by overcoming a series of constraints they are facing

\subsection{Statement of the Problem}

According to (Okpara \& Wynn, 2007) a research on micro and small-business development has shown that the rate of failure of micro and small business enterprises in developing countries is higher than in the developed countries.

Micro and small Businesses are often regarded as high risk operations both locally and globally due to the existence of factors that are difficult to predict adequately (Thomas, 2000). According to (Useem, 2001), it is essential to support and guide micro and small business enterprises in the early stage of establishment by providing them with supervisory and skills related support and supervision. White, (2005) has found that small and mediumsized enterprises often face costly bureaucratic and administrative challenges.

Many researchers conduct a study around the topic of micro and small business enterprises performance and from these; Harash, Al-Timimi \& Alsaadi, (2014), suggests the analysis of the effect of finance on performance of small and medium enterprises in Iraq. Sembiring \& Rasmulia, (2016) has found that knowledge and skills of human resource have a significant effect on the performance of SMEs in Medan city Indonesia. Negash \& Kumera, (2016) Identified that strong competition in the markets, high level of interest rate on loans, poor infrastructure, 
speed of debt payment by customers, unavailability of appropriate property, state of the country's economy, low market demand for firms products or services, pricing of competitor products, unavailability of raw materials, attitude of banks and low availability of finance from lenders were rated as high barriers to growth of medium and small enterprises development in developing country. Abdul, Rahamon \& Adejare, (2014) concluded that there is a strong positive relationship between accounting records keeping and performance of small scale enterprises. Accounting records keeping is essential for decision making which invariably affects performance of small scale enterprises in Nigeria. Woldegebriel M, (2012), has found that lack of business plan, lack of formal and informal business association, lack of favorable business environment, high cost and shortage of raw materials, lack of proper institutional support, lack of proper marketing practice, and stiff competition among MSEs in the same business line and medium and large companies affect performance of SMEs in Addis Ababa. And Addisu Molla, (2010), found that the growth of MSEs is highly influenced by accesses of productive sources and assets in South Wollo Zone.

The rationale of this study will be that the Government established many institutions like, TVET colleges and MFIs to promote the smooth functioning of small business enterprises. NGOs are also promoting small enterprises. However, this sector is not performing up to the expectations of many stake holders as it has been indicated by many researchers. Therefore, conducting such a research seems essential in the light of the fact that different factors affect financial performance of the sector.

At the best knowledge of the researcher, a study which comprise infrastructures, human resources knowledge and skill, government policy, financing, society's perception and market chain problems didn't conducted in Dembi dollo town administration. So, the researcher has taken up this study to fill the gap and test the combined effects of these variables on financial performance of micro and small business enterprises in Dembi dollo town administration.

\subsection{Objectives of the Study}

\subsubsection{General Objective of the Study}

The major objective of the study is examining the factors that affect financial performance of small business enterprises in Dembi dollo town administration

\subsubsection{Specific Objectives of the Study}

- To determine the effect of infrastructures on financial performance of small business enterprises in Dembi dollo town administration

- To examine the effect of human resources knowledge and skills on financial performance of small business enterprises in Dembi dollo town administration

- To determine the effect of access to financing on financial performance of small business enterprises in Dembi dollo town administration

- To determine the effect of government policy on financial performance of small business enterprises in Dembi dollo town administration

- To determine the effects of market chain problems on financial performance of small business enterprise in the town

\subsection{Hypothesis of the Study}

1. There is no significant relationship between infrastructures and financial performance of micro and small business enterprises

2. There is no significant relationship between human resources knowledge and skills and financial performance of micro and small business enterprises

3. There is no significant relationship between financing and financial performance of micro and small business enterprises

4. There is no significant relationship between government policies and financial performance of micro and small business enterprises

5. There is no significant relationship between problems related with marketing and financial performance of micro and small business enterprises

6. There is no a significant relationship between sex of the owners and financial performance of MSEs

7. There is no a significant relationship between number of employees and financial performance of MSEs

8. There is no a significant relationship between age of the enterprise and financial performance of MSEs

9. There is no a significant relationship between type of the enterprise and financial performance of MSEs 


\section{Conceptual Frame Work of the Study}

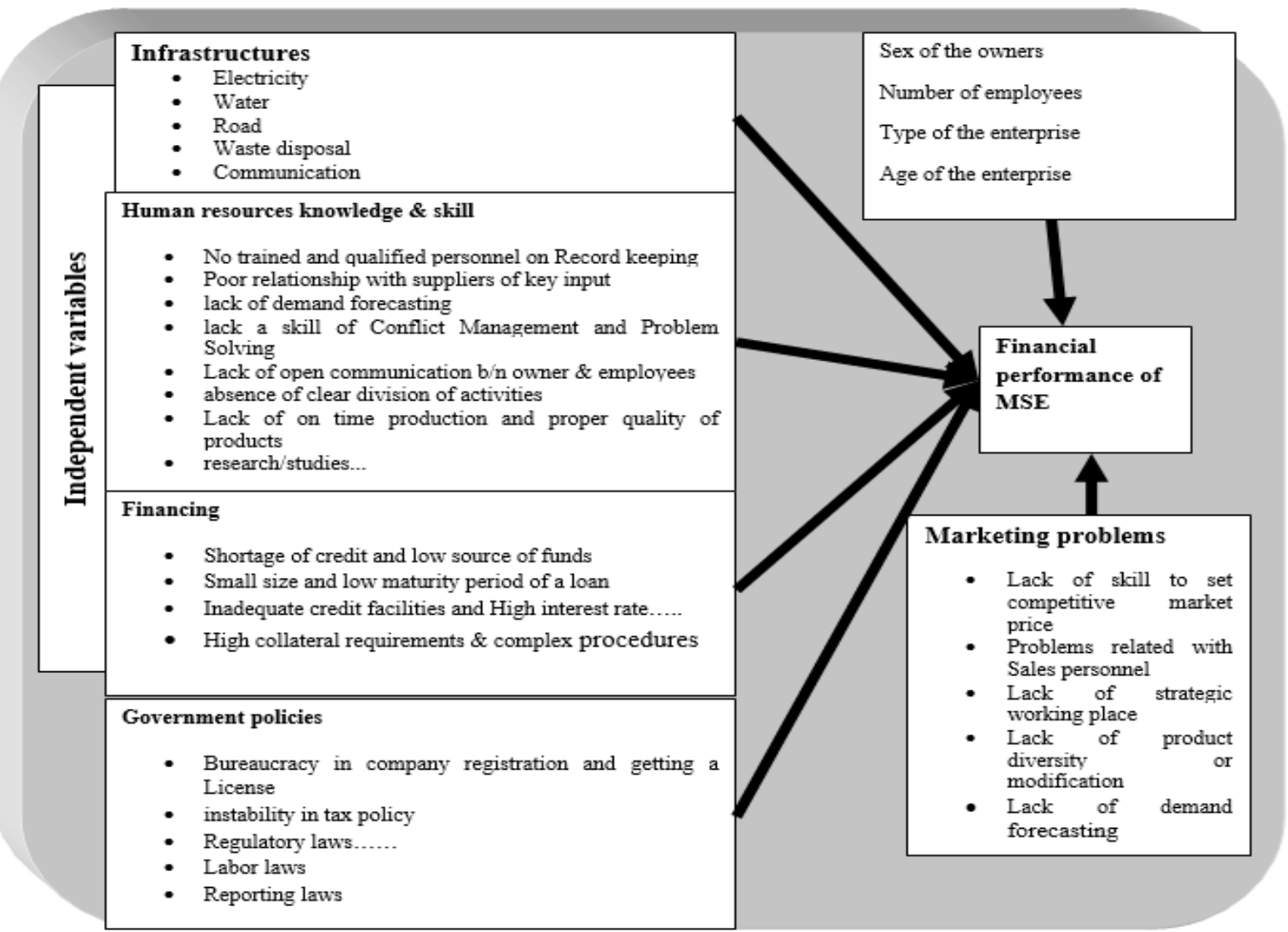

Figure 1: conceptual frame work, developed by the researcher

\subsection{Summary of Empirical Literature Reviews}

\begin{tabular}{|c|c|c|c|c|c|c|c|c|c|c|}
\hline \multirow{2}{*}{$\begin{array}{l}\text { Authors name } \\
\text { and publication } \\
\text { year }\end{array}$} & \multirow{2}{*}{$\begin{array}{l}\text { Type of } \\
\text { data }\end{array}$} & \multirow[t]{2}{*}{ Methodology } & \multicolumn{7}{|c|}{ Empirical Results } & \multirow[b]{2}{*}{ gender } \\
\hline & & & Lackinf & lhrks & lfinc & Pgovt & pmar & entage & age & \\
\hline $\begin{array}{l}\text { Negash } \& \\
\text { Kumera, (2016) }\end{array}$ & $\begin{array}{l}\text { Cross } \\
\text { section }\end{array}$ & OLS & Sign & & sign & & sign & & & \\
\hline $\begin{array}{l}\text { Debarliev \& } \\
\text { Janeska, }(2015)\end{array}$ & $\begin{array}{l}\text { Cross } \\
\text { section }\end{array}$ & OLS & & insig & & & & & & \\
\hline Eniola, (2015) & $\begin{array}{l}\text { Cross } \\
\text { section }\end{array}$ & OLS & & & & sig & & & & \\
\hline $\begin{array}{l}\text { Sembiring \& } \\
\text { Rasmulia, } \\
\text { (2016) }\end{array}$ & $\begin{array}{l}\text { Cross } \\
\text { section }\end{array}$ & OLS & & sig & & & & & & \\
\hline Salam, (2013) & $\begin{array}{l}\text { Cross } \\
\text { section }\end{array}$ & OLS & & & sig & & & & & \\
\hline $\begin{array}{l}\text { Abdul- } \\
\text { Rahamon \& } \\
\text { Adejare, (2014) }\end{array}$ & $\begin{array}{l}\text { Cross } \\
\text { section }\end{array}$ & OLS & & sig & & & & & & \\
\hline $\begin{array}{l}\text { Yusuff, } \\
\text { Olagbemi \& } \\
\text { Atere, }(2015)\end{array}$ & $\begin{array}{l}\text { Cross } \\
\text { section }\end{array}$ & OLS & & & & & & & & Sig \\
\hline $\begin{array}{l}\text { Akinbogun, } \\
(2008)\end{array}$ & $\begin{array}{l}\text { Cross } \\
\text { section }\end{array}$ & OLS & & & & sign & & & & \\
\hline $\begin{array}{l}\text { Woldegebriel } \\
\mathrm{M},(2012)\end{array}$ & $\begin{array}{l}\text { Cross } \\
\text { section }\end{array}$ & Logit & Sign & & & & sign & & & \\
\hline $\begin{array}{ll}\text { Addisu } & \mathrm{M}, \\
(2010)\end{array}$ & $\begin{array}{l}\text { Cross } \\
\text { section }\end{array}$ & OLS \& Logit & & & sig & & sig & & insig & Insig \\
\hline
\end{tabular}




\section{Research Methodology}

\subsection{Description of the Study Area}

The focus of the study is Dembi dollo town administration. Dembi dollo formerly sayo is a market town and separate woreda in south western Ethiopia. It is mostly known by its gold and busy cash crop business including coffee arabica. It is the capital of kelam wolega zone of the oromia region and it exists on the distance of $631 \mathrm{kms}$ from Addis Ababa, the center of Ethiopia.

\subsection{Research Design}

This study employed a descriptive type of cross-sectional and explanatory research design which is used when the problem has been defined specifically and where the researcher has certain issues to be described by the respondents about the problem (Kothari, 2004).

Descriptive research design was used in order to explain and describe the factors that affect financial performance of small business enterprises in Dembi dollo town administration. The study also used cross-sectional type of research design; because the data was collected from the sample participants who take part in the study once only.

\subsection{Research Approach}

The researcher used a mixed research approach; i.e. both qualitative and quantitative research approaches. The quantitative approach provides an objective measure of reality, on the other hand, the qualitative approach allows the researcher to explore and better understand the complexity of a phenomenon. Both quantitative and qualitative research approaches may have their own strengths and limitations. According to Sale et al, (2002) the advantage of a quantitative research approach may be limitations for a qualitative approach and vice versa. So the researcher was supposed to use a mixed research approach in order to fill the limitation of one approach by the strength of the other approach.

\subsection{Target Population of the Study}

The target population for this study was 3361 micro and small business enterprises which exist in Dembi dollo town administration and formally registered by trade and industry office of the town.

\subsection{Sample Size}

Hazelrigg, (2009) states that "as when setting confidence intervals, there is nothing sacrosanct or magical about these numbers, either $Z$ or alpha. They are entirely conventional choices, and one is free to select a different number. At a confidence level of $95 \%$, and the margin of error of $5 \%$, to obtain a sample size that has an adequate size relative to the goals of the study, the researcher adopted Yamane's formula as follows:

$$
\mathrm{n}=\frac{N}{1+N(e) 2}
$$

Where;

' $\mathrm{n}$ ' = sample size

"N" = population size and

"e" = margin of error (Yamane, 1967)

$\frac{3361}{(1+3361(0.05)) 2}=358$

A sample size of 358 respondents was used to analyze and achieve the objective of the study.

Table 1: Proportionate Sample Size Determination from Each Stratum

\begin{tabular}{|l|l|l|}
\hline Category & Target population & Sample size \\
\hline Manufacturing & 1768 & $188=(1768 / 3361 * 358)$ \\
\hline Construction & 326 & $35=(326 / 3361 * 358)$ \\
\hline Service & 627 & $67=(627 / 3361 * 358)$ \\
\hline Urban agriculture & 158 & $17=(158 / 3361 * 358)$ \\
\hline Merchandising & 482 & $51=(482 / 3361 * 358)$ \\
\hline Total & 3361 & 358 \\
\hline
\end{tabular}

Source: developed for this study by the researcher

\subsection{Sampling Technique of the Study}

The study used stratified probability sampling technique which is one of the sampling techniques under probability sampling to select the enterprises and to select the respondents the researcher will use simple random sampling technique. Stratified probability sampling method will be used because by nature, small enterprises exist in the form of strata. So using stratified probability sampling technique is important here to incorporate all sectors of the business proportionally. Simple random sampling technique will be used in order to avoid biases and to give equal 
chance to the sample participants.

\subsection{Type and Sources of the data}

The researcher used both primary and secondary types of data. The source of the data was micro and small business enterprise owners which exist in Dembi dollo town administration.

\subsection{Methods of Data Collection}

The data was collected through questionnaires and from the sample respondents of the study.

The questionnaires were prepared in English language; however, it was translated into the local language in order to make the questions simple, clear, and understandable to the respondents.

\subsection{Methods of Data Analysis}

The raw data obtained from the respondents was analyzed and interpreted by running STATA version 12 . The focus of this study was to find out the link between independent variables such as, infrastructures, human resource knowledge and skills, access to financing, government policy and problems related with marketing with the dependent variable, financial performance of micro and small business enterprises.

The study measured financial performance, through return on investment of the enterprises. The data was collected from the small business enterprise owners through questionnaires in the form of average annual profits and their initial investments.

\subsection{Reliability and Validity of Instruments}

According to Bryma \& Bell, (2003) the Cronbach's Alpha result of 0.7 and above implies acceptable level of internal reliability. So; the internal consistency coefficient alpha was calculated to determine whether the items in a scale will all measuring the same underlying construct and the result for alpha is 0.8572 as indicated on appendix II.

On the other hand to assure validity, questionnaires will be designed on the basis of previous studies' questionnaires and review of related literature.

\subsection{Ethical Consideration}

Standard ethical guidelines and procedures were followed for gathering data from each of the small business enterprise operators who take part in the study. Each of the participants takes part in the study voluntarily and an explanation was provided to each of the respondents about the purpose of the study, along with their right to drop out of the study without having to explain why. They were informed that responses obtained from each participant will be kept in confidence and respondents will not be exposed to any risk as a result of taking part in the study.

\section{Results and Discussion}

Table 4.2 Mean of Investments, Average Profit and Return on Investments

\begin{tabular}{c|rrrr} 
Mean estimation & & Number of obs & 348 \\
\hline & Mean & std. Err. & {$[95 \%$ Conf. Interva1] } \\
\hline investment & $\mathbf{4 5 2 7 . 8 6}$ & $\mathbf{1 7 6 6 . 6 6 3}$ & $\mathbf{4 1 8 0 1 . 1 5}$ & $\mathbf{4 8 7 5 0 . 5 8}$ \\
avprofit & $\mathbf{9 8 2 5 . 4 8 9}$ & $\mathbf{7 1 2 . 9 6 4 5}$ & $\mathbf{8 4 2 3 . 2 1 3}$ & $\mathbf{1 1 2 2 7 . 7 6}$ \\
Roi & .204692 & .0079819 & .188993 & .2203909
\end{tabular}

The above table indicates that the mean of micro and small enterprise owner's return on investment is $20.4692 \%$, mean of their investment 45275.86 and mean of their average annual profit is 9825.489 
4.1 Multiple Regression Analysis Results

4.1.1 Goodness of Fit, Model Summary and Coefficients

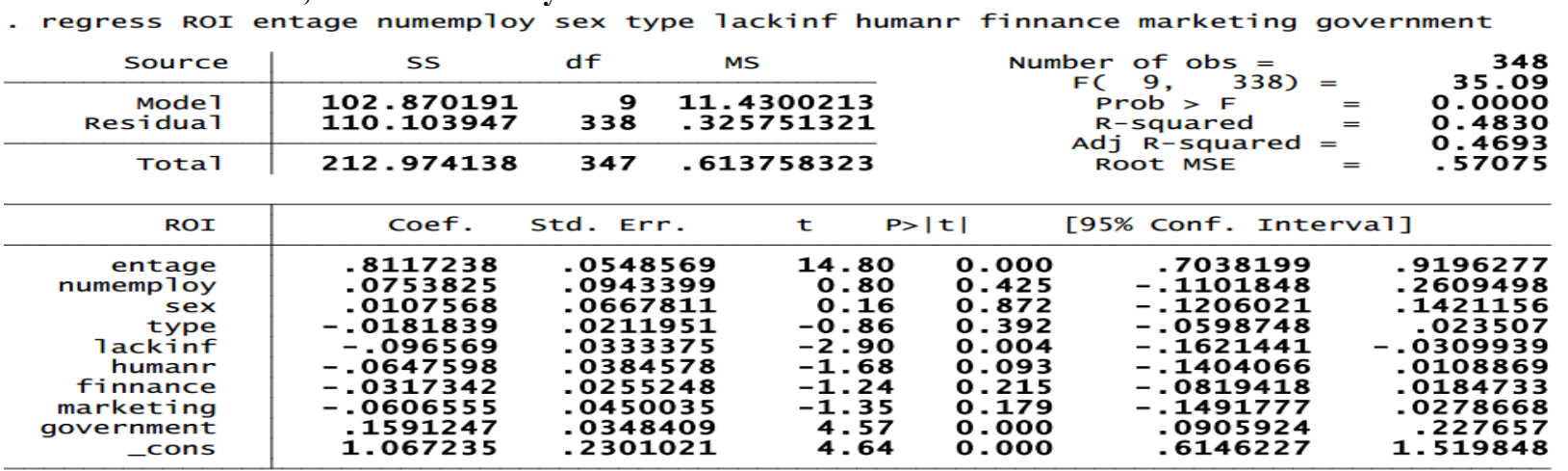

Results on table 4.8: presents the goodness of fit of the regression model which shows that the effect of infrastructures, human resources knowledge and skill, financing, government policies, marketing problems, type of the enterprise, sex of the respondents, the age of the enterprise and number of employees on financial performance of micro and small business enterprises. The model is statistically significant in explaining changes in financial performance as demonstrated by a ' $\mathrm{P}$ ' value of 0.000 which is less that the acceptance alpha value of 0.05

From the regression results on the above table 4.8: the value of adjusted $\mathrm{R}$ squared (co-efficient of determination) is 0.4693 which is an indication that there is a variation of $46.93 \%$ on financial performance of small business enterprises due to changes in infrastructures, human resources knowledge and skill, financing, government policies, marketing, type of the enterprise, sex of the owners, age of the enterprise, and number of employees at $95 \%$ confidence interval. This shows that $46.93 \%$ changes on financial performance of small business enterprises could be accounted for by changes in infrastructures, human resources knowledge and skill, financing, government policies, marketing, type of the enterprise, sex of the owners, age of the enterprise, and number of employees.

The study established that shortage of infrastructures $(\beta=-0.0965 \& \mathrm{P}=0.004)$ and lack of human resources knowledge and skill $(\beta=-0.06475 \& \mathrm{P}=0.093)$, have a negative significant effect on financial performance of micro and small business enterprises. That means when there is a decrease in supply of infrastructures facility and human resources knowledge and skill financial performance of micro and small business enterprises diminishes. On the other hand improvement in supply of infrastructures and human resources knowledge and skill improves financial performance of micro and small business enterprises. I.e. infrastructures, human resources knowledge and skill have a direct relationship with financial performance of small business enterprises.

On the other hand the study established a positive significant relationship between government policies and financial performance of small business enterprises $(\beta=0.159 \& \mathrm{P}=0.000)$ and age of the enterprises $(\beta=0.811$ $\& \mathrm{P}=0.000) \mathrm{A}$ decrease in government regulatory laws rigidness and increase flexibility in government policies and increase in age of the enterprise would increase financial performance of micro and small business enterprises. I.e. government policies and financial performance of micro and small business enterprises has indirect relationship and on the other hand age of the enterprises and financial performance of micro and small business enterprises have direct relationship.

\subsubsection{Confirmation of the Hypothesis}

1 . $\mathrm{Ho}=$ There is no a significant relationship between infrastructures and financial performance of small business enterprises

As evidenced from the above regression result, Ho: were rejected in favor of H1: $(p=0.004 \& \beta=-0.0965)$ in which the 'P' value is less than the acceptable alpha value: $0.004<0.05$ )

According to the findings of this study infrastructure related problems have a negative significant effect on financial performance of micro and small business enterprises $(p=0.004 \& \beta=-0.0965)$ at a significant level of 5\%. Thus, the researcher rejects Ho.

2. $\mathrm{Ho}=$ There is no significant relationship between human resources knowledge and skill and financial performance of micro and small business enterprises

As evidenced from the above regression result, Ho: were rejected in favor of $\mathrm{H} 1:(p=0.093 \& \beta=-0.06475)$ at $10 \%$ level of significance ' $P$ ' value is less than the acceptable alpha value: $0.093<0.1$ )

According to the findings of this study lack of human resources knowledge and skill have a negative significant effect on financial performance of micro and small business enterprises $(\beta=-0.06475 \& \mathrm{P}=0.093)$ at a significance level of $10 \%$. Thus, this study rejects Ho.

3. Ho=There is no significant relationship between financing facilities and financial performance of micro and 
small business enterprises

As evidenced from the above regression result, fail to reject Ho, in favor of $\mathrm{H} 1$ : $(\mathrm{p}=0.215 \& \beta=-0.03173)$ the ' $\mathrm{P}$ ' value is greater than the acceptable alpha value: $(0.215<0.05)$

4. $\mathrm{Ho}=$ There is no significant relationship between government policies and financial performance of micro and small business enterprises

As evidenced from the above regression result, Ho: was rejected in favor of $\mathrm{H1}:(\mathrm{p}=0.000 \& \beta=0.159)$ that the ' $\mathrm{P}$ ' value is less than the acceptable alpha value: $0.000<0.05$ )

According to the findings of this study non-existence of problems related with government policies have a positive significant effect on financial performance of small business enterprise $(\beta=0.159 \& \mathrm{P}=0.000)$ at a significance level of $5 \%$.Thus, this research rejects Ho.

5. Ho $=$ there is no significant relationship between problems related with marketing and financial performance of micro and small business enterprises

As evidenced from the above regression result, fail to reject Ho in favor of $\mathrm{H} 1$ : $(\mathrm{p}=0.179 \& \beta=-0.0606)$ the ' $\mathrm{P}$ ' value is greater than the acceptable alpha value: $(0.215<0.05)$

6. Ho: There is no a significant relationship between age of the enterprises and financial performance of MSEs

As evidenced from the above regression result, Ho was rejected in favor of $\mathrm{H} 1(\beta=-0.811 \& \mathrm{P}=0.000)$ because the ' $p$ ' value is less than the acceptable alpha value

7. Ho: there is no significant relationship between sex of the owners and financial performance of SMEs

As evidenced from the above regression result, fail to reject Ho in favor of $\mathrm{H} 1$ because the "p" value is greater than the acceptable alpha value

8. Ho: there is no a significant relationship between type of the enterprises and financial performance of SMEs As evidenced from the above regression result, fail to reject Ho in favor of $\mathrm{H} 1$ because 'p' value is greater than the acceptable alpha value

9. Ho: there is no significant relationship between number of employees and financial performance of MSEs As evidenced from the above regression result, fail to reject Ho in favor of $\mathrm{H} 1$ because the ' $\mathrm{p}$ ' value is greater than the acceptable alpha value

\subsubsection{Discussion of the Findings}

\subsubsection{Infrastructures and Financial Performance}

The first objective of the study was to determine the effect of infrastructures on financial performance of micro and small business enterprises. Descriptive results indicated that majority of the respondents agreed with the existence of lack of infrastructures facility in the town. This was evidenced by the respondents response who agreed to the statements, such as there is frequent break up of electric power, there is in adequate water supply, there is frequent network problem, there is high rate of per minute tariffs in Telephone or communication service, there is a problem of non-maintenance of broken roads and inadequate road construction and there is unavailability of appropriate waste disposal and other related services and finally most of the respondents agreed that lack of these facilities strongly affect financial performance of micro and small business enterprises in the town.

As evidenced from the regression results, the relationship between lack of infrastructures and financial performance of small business enterprises is negative and significant at a significance level of $5 \%$ ( $p=0.004 \& \beta=$ -0.0965). The findings imply that an increased level of infrastructures deficiency is associated with a decreased level of small business enterprises financial performance, on the other way an increased level supply of infrastructures leads to increased level of performance. I.e. financial performance of small business enterprises is directly related with supply of infrastructures and numerically if the supply of infrastructures decreased by 1 unit financial performance of micro and small business enterprises will decrease by $9.65 \%$

This finding is consistent with the findings of Fatoki Olawale \& David Garwe, (2010) in which access to infrastructure is reported as a significant problem. This study simultaneously revealed that infrastructure really influences the performance of micro and small business enterprises because with infrastructure (power supply, water supply, road, transportation, telecommunication and the rest) small business enterprises perform extraordinary well, indicates that small enterprises success lays on the neck of infrastructure that is why there is need to have adequate infrastructure on ground so that performance of micro and small enterprises can be achieved in Dambi dollo town administration.

Other studies such as Okpara, (2011), Rahel \& Paul, (2010) and Woldegebrel M, (2012), revealed that infrastructures do not have a significant effect on the performance of micro and small business enterprises. Meaning that infrastructures are not the factors that influence the performance of micro and small business enterprises that is why their study findings were contrary to this study.

This study is also consistent with the scholars Kimuyu, Kayizzi \& Mugerwa, (1998) Where there is absence or shortage provision of infrastructures, such as electricity, good roads and appropriate waste disposal the enterprise goes to self-provision, which the enterprise may not fully, be able to internalize into its pricing structure. As a result, self-provision twists the costs structure and the points of optimality that the firms maximize profits subject to cost efficiency. Therefore, the researcher can conclude as the infrastructure development within a town 
such as the status of roads, telecommunications, transport and electricity have a positive impact on the growth and performance of micro and small business enterprises.

\subsubsection{Human Resources Knowledge and Skill and Financial Performance}

The second objective of the study was to determine the effect of human resources knowledge and skill on financial performance of micro and small business enterprises. Descriptive results indicated that majority of the respondents agreed with the existence of lack of human resources knowledge and skill in micro and small business enterprises. This was evidenced by the respondents response who agreed to the statements such as, there is lack of skill about marketing research or studies, there is lack of skill to search and use business information, micro and Small business enterprise operators' has limited skill and management capacity to develop a strategic plan, no performance evaluation of actual results against plans on continuous basis, there is no trained and qualified personnel assigned on record keeping, there is poor relationship with suppliers of key input and finally most of the respondents agree that lack of these human resources knowledge and skills in the enterprise strongly affects micro and small business enterprises financial performance in the town.

As evidenced from the regression result, the relationship between lack of human resources knowledge and skills and financial performance of small business enterprises is negative and significant at a significance level of $10 \%(p=0.093 \& \beta=-0.06475)$. The findings imply that a decrease in human resources knowledge and skills is associated with a decreased level of micro and small business enterprises financial performance, on the other way an increased level of human resources knowledge and skills leads to increased level of performance. I.e. financial performance of micro and small business enterprises is directly related with human resources knowledge and skills and numerically a unit decrease in human resources knowledge and skill decreases financial performance of MSE performance by $6.475 \%$.

This finding is consistent with the findings of Sembiring, Rasmulia, (2016) in which independent variables knowledge and skills of human resources have a positive and significant effect on the performance of small business enterprises. This means that the higher the knowledge and skills of human resources, the better the performance of small business enterprise and vice versa.

Therefore, knowledge and skills need to be upgraded and maintained to encourage employees to achieve better performance, which in turn will contribute to increase in performance of micro and small business enterprises.

The finding of this study is inconsistent with debarliev \& Iliev, (2015) study in which the effect of human resources knowledge and skill on growth is negative and statistically insignificant.

But the positive and significant influence of variables of knowledge and skills is in line with the theory that human resources knowledge and skill plays an important role in preparing qualified and competitive human. It is due to the fact that knowledge and skill becomes the center of all changes and must be addressed appropriately. The skill of supporting human resources is one of the factors in improving the performance of small business enterprise. By the availability of high skilled human resources to manage micro and small business enterprises, it is expected that better performance in these enterprises will be attained.

Skill and knowledge of owner and employees in micro and small business are very often related with the theories of human capital, where it is stressed that enterprises with more or higher quality human capital achieve higher performance in executing relevant tasks (Becker, 1975). One important extension of the resource-based view is the energetic capabilities perspective. Teece et al., (1997) argue that dynamic capabilities enable enterprises to integrate, build, and reconfigure their resources and competencies and, therefore, maintain performance in the face of changing business environments. Many authors provide empirical evidence of a positive association between employees' skills and knowledge and firm performance.

\subsubsection{Government policies and financial performance of micro and small enterprises}

The fourth objective of the study was to determine the effect of government policies on financial performance of small business enterprises. Descriptive results indicated that majority of the respondents agreed with the existence of problems related with bureaucracy in company registration and getting a license and uncertainty, inconsistency and instability in tax policy. but most of the respondents were disagreed with the existence of the following problems; such as, regulatory laws (standards that affect how businesses operate in specific situations), labor laws (regulations that relate directly to how businesses treat employees) and reporting laws (control how businesses must report their finances to investors and the government) and finally most of the respondents agreed that problems related with government policies strongly affects small business enterprises financial performance. But in Dembi dollo town administration from the raised questions only two of them are existing and three of the problems are not exist.

As evidenced from the regression result, the relationship between problems related with government policies and financial performance of small business enterprises is positive and significant at a significance level of $5 \%$ $(p=0.000 \& \beta=0.159)$. This was unexpected finding, that problems related with government policies should become negative. But the logic is here, as evidenced from the descriptive statistics from the asked five government policies related problems only two's exist in dembi dollo town administration. The other three problems do not 
exist. So, the positive sign was the indicator that the marginal effects of non-existing problems are greater than the marginal effect of existing problems and shows that nonexistence such government policy related problems positively contributes to the financial performance of small business enterprises.

The findings imply that when government related policies rigidness decreases, it is associated with an increased level of micro and small business enterprises financial performance, on the other way an increased level of government policies rigidness leads to a decreased level of performance. I.e. financial performance of small business enterprises is indirectly related with the level of government policies rigidness, numerically a unit decrease in government policies rigidness leads to increase financial performance of MSE by $15.9 \%$.

This finding is consistent with the findings of Eniola \& Entebang, (2015) in which government policy was reported as; it has a major impact on the competitiveness and profitability of small business enterprises.

And this result is consistent also with the theory; firms can improve their production capacity and can also perform well if the government policies remain stable. Because frequent changes in tax policies, rigid government policies, Bureaucracy, Regulatory issues etc. have made the entrepreneurs unhappy regarding with their own industries. This will affect the development and performance of small business enterprises negatively and discourages their productivity

\subsubsection{Age of the enterprises and financial performance of micro and small enterprises}

Descriptive results indicated that majority of the respondents business are young or from 2 to 5 years. As evidenced from the regression result, the relationship between age of the enterprises and financial performance of them is negative and significant $(\beta=0.811 \& \mathrm{P}=0.000)$ this is due to the fact that when the age of enterprises increases their financial performance will be increase.

This finding is consistent with the findings of Addisu M., (2010) in which age of the enterprises has a positive significant effect on the growth of micro and small business enterprises in south wollo zone.

And this result is consistent also with the theory; firms can improve their production capacity and can also perform economies of scale when they become big and exist longer on the business environment.

\section{Conclusions and Recommendations}

\subsection{Conclusions}

The general objective of the study was to determine factors that affect financial performance of small business enterprises in dembi dollo town administration. In order to achieve the major objective, there were four specific objectives.

The first specific objective of the study was to determine the effect of infrastructures on financial performance of MSEs in dembi dollo town administration. Accordingly, the study identified as; frequent break up of electric power, in adequate water supply, frequent network problems, high rate of per minute tariffs in telephone or communication service, non-maintenance of broken roads and inadequate road construction and unavailability of appropriate waste disposal and other related services as high barriers for financial performance of MSEs.

The second objective of the study was to determine the effect of human resources knowledge and skill on financial performance of MSEs in dembi dollo town administration. Accordingly, the study identified as, lack of skill about marketing research or studies, lack of skill to search and use business information, small business enterprise operators' limited skill and management capacity to develop a strategic plan, no performance evaluation of actual results against plans on continuous basis, poor relationship with suppliers of key input, lack of open communication $\mathrm{b} / \mathrm{n}$ owner/manager and employees, due to Fear of failure, bankruptcy and risk taking and small enterprises didn't take possible business opportunities as high barriers for financial performance of MSEs.

The fourth specific objective of the study was to determine the effect of government policies on financial performance of MSEs in Dembi dollo town administration. Accordingly, the study identified as; bureaucracy in company registration and getting a license and uncertainty, inconsistency and instability in tax policy and high tax rate as high barriers for financial performance of MS business enterprises.

\subsection{Recommendation}

The main objective of the study was to identify factors that affect financial performance of small business enterprises in Dembi dollo town administration and suggest possible recommendations to overcome the problems. Therefore, based on the findings of the study, the following recommendations are suggested to the concerned bodies.

The quality and accessibility of infrastructures should be considered. Because the absence of infrastructures like (electricity, water, quality road and working place) negatively and significantly affects financial performance of MSEs in the town. So, in order to attain higher performance of the enterprises, the government and other concerned bodies in the development of small business enterprises should solve problems related with supply, accessibility and shortage of infrastructures by applying the following infrastructures facility improvement possibilities such as; by repairing the existing broken systems and by promoting and sustainable systems for new infrastructural development, by limiting the governments control of infrastructure system and encourage 
unsubsidized private investment, competition and innovation,

The study shows that lack of human resources knowledge and skill have a negative significant influence on financial performance of MSEs. In order to improve small business enterprises performance, it is pivotal to pay attention to human resource knowledge and skill. To enjoy the differentiating factor of unique human capital, the organizations should offer continuous human resources training and development to their staff members and the government and other concerned bodies in the development of small business enterprises should assist small enterprise owners by providing different business training facilities and sharing experiences and this facility will be arranged by the town's small and micro enterprises office it will be arranged through payment wise with universities and colleges or voluntary support basis.

The government should give attention related with bureaucracy in company registration and getting a license and uncertainty, inconsistency and instability in tax policy and high tax rate in the town because these problems negatively and significantly affects small business enterprises performance in the town.

\section{References}

Adejugbe, A., (2013) Foreign Direct Investment in Nigeria: Overcoming Legal and Regulatory Challenges to Foreign Direct Investments in Nigeria. Is the Nigerian Government Doing Enough? SSRN Electronic Journal Becker, G.S., (1975) Human Capital: Chicago University Press Chicago. Beer, M. Eisenstat

Belay, G., (2000) Evaluation of the Performance of the Private Sector Economy in Ethiopia (1991-1999). Addis Ababa: Ethiopian Ministry of Trade and Industry.

Bryman, A., \& Bell, E., (2003) Business Research Methods: Oxford University Press Inc. New York

De Kok, J., Vroonhof, P., Verhoeven, W., Timmermans, N., Kwaak, T., Snijders, J., and Westhof, F., (2011) Do SMEs Create More and Better Jobs? Report EIM Business \& Policy Research. Brussels.

Gebrehiwot, G., (2006) Managerial Performance Measurement in Small Scale Industries: Graduate Studies of Addis Ababa University. Addis Ababa

Hazelrigg, L., (2009) the Handbook of Data Analysis: Sage, London, UK.

Kothari, C., (2004) Research Methodology: Methods \& Techniques $2^{\text {nd }}$ edition, New age International Publishers. New Delhi, India

Laban, K. dan, \& Sirine, H., (2014) The Effect of Life Quality Performances on the Workers' Performances of SMEs in Salatiga: Jurnal Inovasidan Kewirausahaan. 3, 129-144.

Levy, B., (2015) Obstacles to Developing Indigenous Small and Medium Enterprises: An Empirical Assessment the World Bank Economic Review. 7 (1), 65-83

Liedholm, C., MacPherson, M.,\&Chuta, E., (2007) Small Enterprise Employment Growth in Rural Africa: American Journal of Agricultural Economics Vol. 76, 10-15.

Negash \& Kumera, (2016) Barriers to Growth of Medium and Small Enterprises in Developing Country: Journal of Entrepreneurship \& Organization Management. jimma university, Ethiopia

Okpara, J. O., (2011) Factors Constraining the Growth and Survival of SMEs in Nigeria: Management Research Review. 34(2), 156-171

Okpara, J.O.,\& Wynn, P., (2007) Determinants of Small Business Growth Constraints in a Sub-Saharan African Economy: SAM Advanced Management Journal. 72(2), 24-35

Purwidianti, W., (2015) Internal Factor Effect toward SMEs Performances in North Purwekerto: Journal Article. 19 (1): 149-159.

Rahel, W., \& Paul, I., (2010) Growth determinants of women-operated micro and small enterprises in Addis Ababa: Journal of Sustainable Development in Africa 12/6, 233-246

Saito, K.,\& Villanueva, (2000) Transactions Costs of Credit to the Small Scale Sector in the Philippines: Economic Development and Cultural Change. (29), 3

Sale, et al., (2002) Revisiting the Quantitative-Qualitative Debate: Implications for Mixed Methods Research, Quality \& Quantity 36(1).

Sembiring \& Rasmulia, (2016) Impact of Human Resources' Knowledge and Skills on SMEs' in Medan City Indonesia: International Journal of Management, Economics and Social Sciences. (IJMESS), ISSN 23041366, Vol. 5, Iss. 3, pp. 95-104

Thoms, A.S., (2000) a Case for Comparative Entrepreneurship: Assessing the Relevance of Culture. Journal of International Business Studies, 31(2): 287-303

Tushabonwe- Kazooba, C., (2006) Causes of Small Business Failure in Uganda: A Case Study from Bushenyi and Mbarara Towns: African Studies Quarterly. 8(4)

Van Stel, A. J., \& D. J. Storey., (2004) the Link between Firm Births and Job Creation: Is there an up as Tree Effect? Regional Studies 38(8) 893-909

Weldegbriel M., (2012) Problems of Micro and Small Enterprises in Addis Ababa: The Case of Kirkos, Kolfe, and Yeka Sub Cities (MA Thesis in Master of Business Administration in Management) Addis Ababa University

Wolday, A., \& Gebrehiwot, A., (2004) Business Development Services In Ethiopia: Status, Prospects, and 
Challenges in the Micro and Small Enterprise Sector. A Paper Presented in the International Conference on

Micro finance Development in Ethiopia, 21-25 Jan 2004, Awassa, Ethiopia.

Appendix I: Regression results

- regress ROI entage numemploy sex type lackinf humanr finnance marketing government

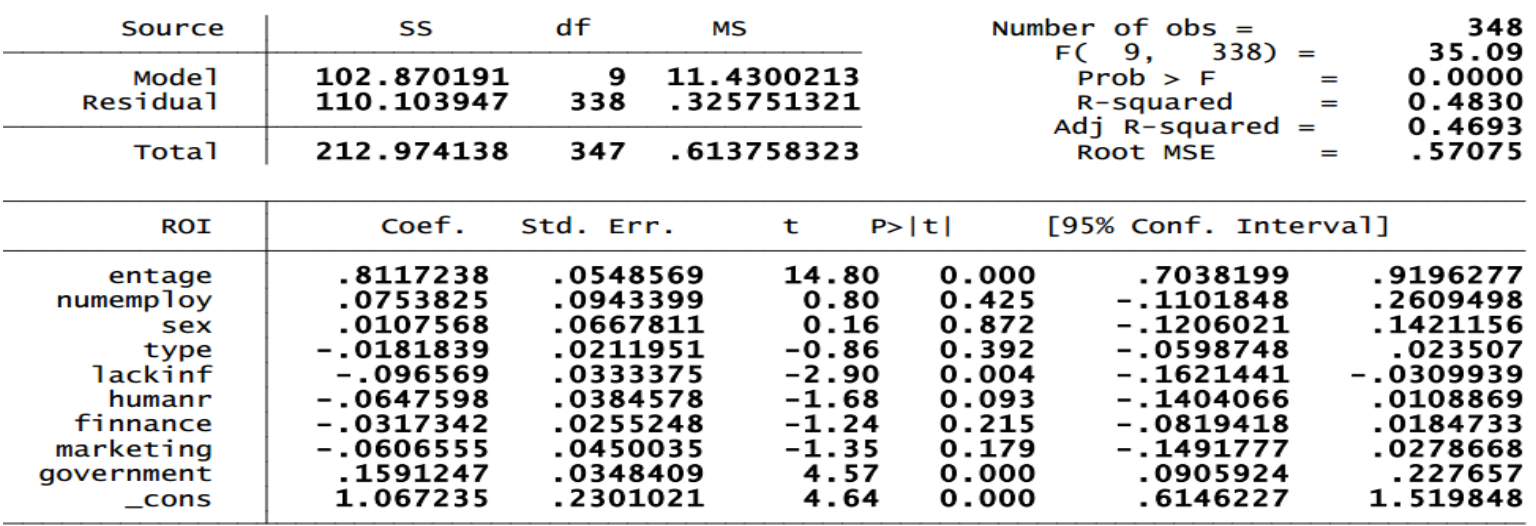

Appendix II: Test of Normality and Linearity

swi $7 \mathrm{k}$

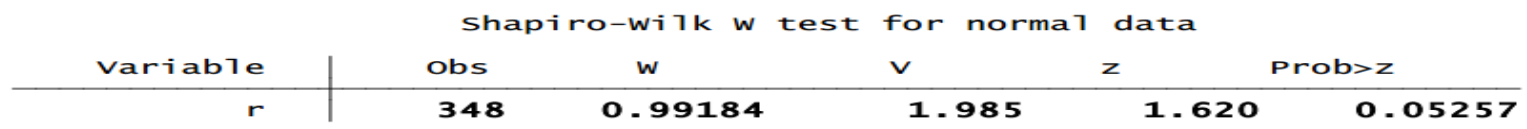

- ovtest

Ramsey RESET test using powers of the fitted values of ROI

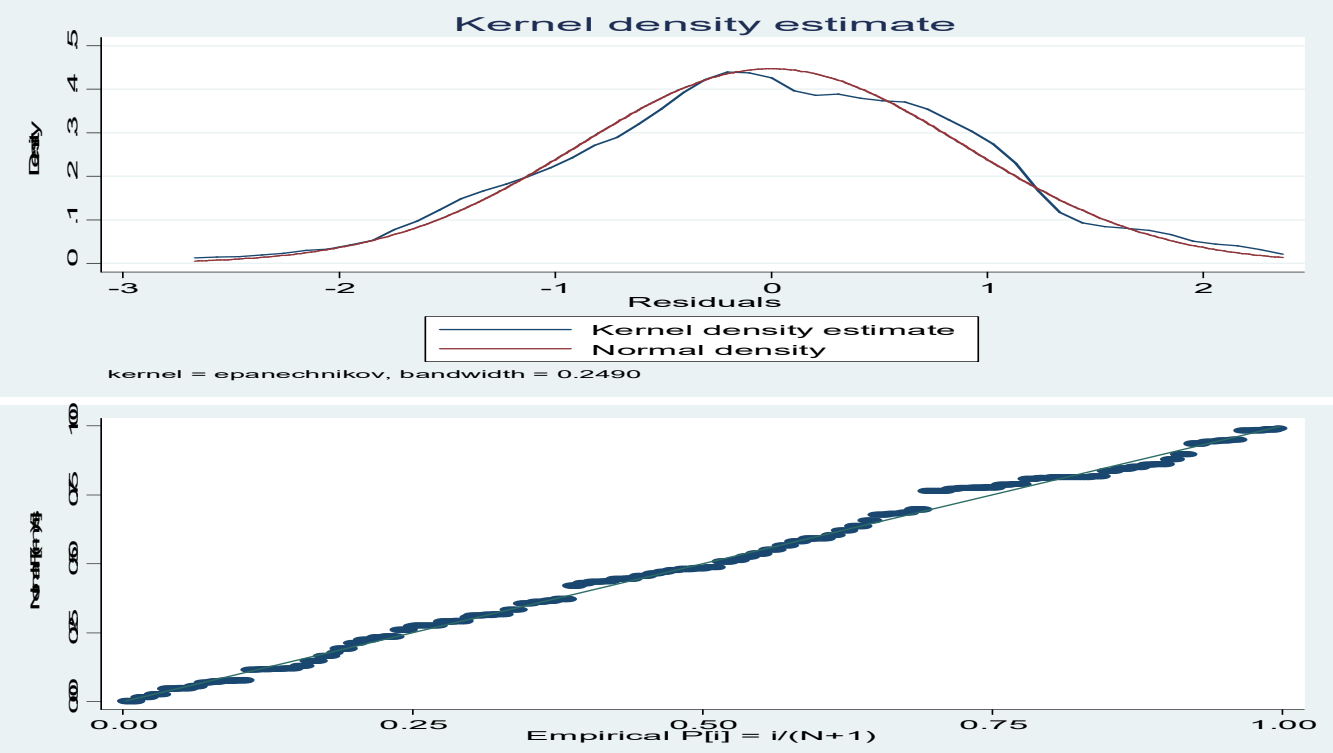

Appendix III: Test of Heteroskedasticity

- hettest

Breusch-pagan / cook-weisberg test for heteroskedasticity Ho: constant variance

variables: fitted values of ROI

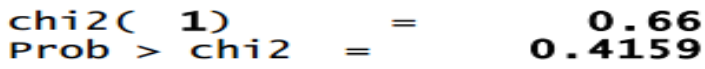




\section{Appendix IV: Test of Multicollinearity Pwcorr}

- pwcorr ROI government marketing finnance humanr lackinf type sex entage numemploy

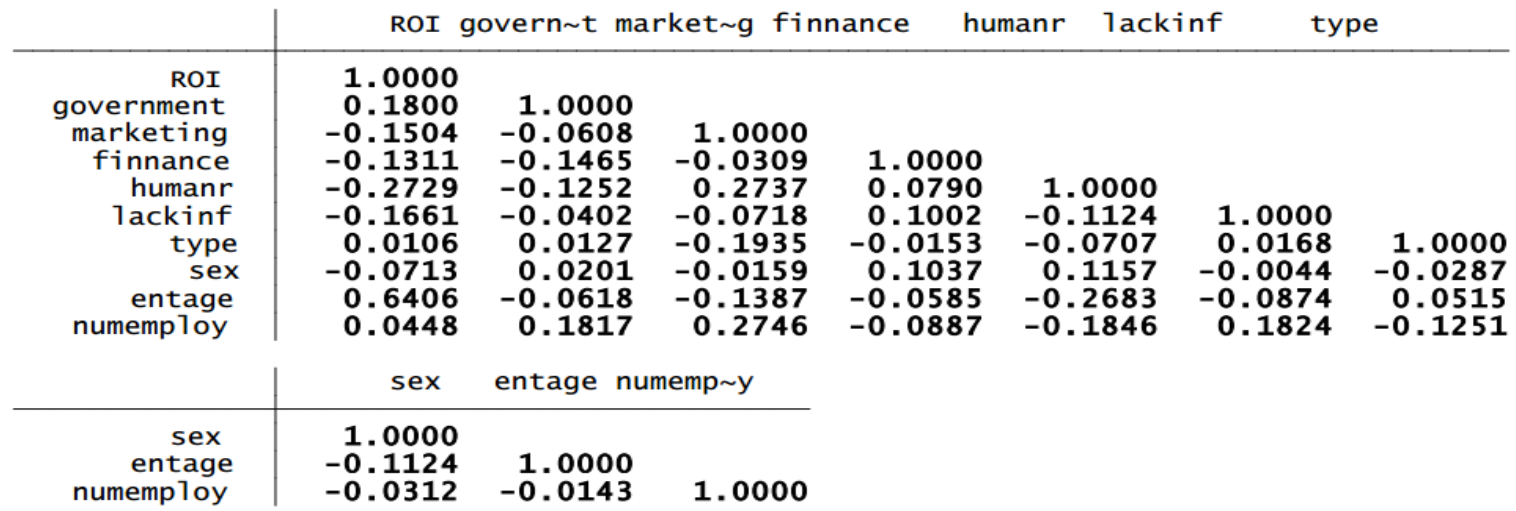

Appendix V: Test of Model Specification

- ovtest

Ramsey RESET test using powers of the fitted values of ROI Ho: model has no omitted variables $F(3,335)=1.00$ Prob $>\bar{F}=\quad 0.3946$

Appendix VI: Data Reliability Test - Alpha

Average interitem covariance: $\quad .1074099$

Number of items in the scale: 53

scale reliability coefficient: $\quad 0.8572$

\begin{tabular}{|c|c|c|c|c|}
\hline \multicolumn{5}{|c|}{ Appendix III: Operation Definition of Dependent and Independent Variables } \\
\hline variable & $\mathrm{N}$ & Variable definition & Measurement scale & Mean \\
\hline ROI & 348 & Return on investment & Scale & .204692 \\
\hline lackinf & 348 & Lack of infrastructures & $\begin{array}{l}\text { Ordinal }(1=\text { strongly agree } 5=\text { strongly } \\
\text { disagree })\end{array}$ & \\
\hline numemploy & 348 & $\begin{array}{l}\text { Number of employees } \\
\text { within the enterprise }\end{array}$ & $\operatorname{Ordinal}(1=1-5,2=6-10)$ & \\
\hline sex & 348 & Sex of the enterprises & dummy $(1=$ male, $0=$ female $)$ & \\
\hline humanr & 348 & $\begin{array}{l}\text { Human resources } \\
\text { knowledge and skill }\end{array}$ & $\begin{array}{l}\text { Ordinal }(1=\text { strongly agree } 50=\text { strongly } \\
\text { disagree) }\end{array}$ & \\
\hline type & 348 & Type of enterprises & $\begin{array}{l}\text { Nominal }(1=\text { manufacturing, } 2=\text { service }, 3 \\
=\text { merchandising, } 4=\text { construction, } 5=\text { urba } \\
\mathrm{n} \text { agriculture })\end{array}$ & \\
\hline finnance & 348 & Lack of access to finance & $\begin{array}{l}\text { ordinal }(1=\text { strongly agree, } 5=\text { strongly } \\
\text { disagree })\end{array}$ & \\
\hline government & 348 & $\begin{array}{l}\text { Problems related with } \\
\text { government policies }\end{array}$ & $\begin{array}{l}\text { Ordinal ( } 1=\text { strongly agree, } 5=\text { strongly } \\
\text { disagree }\end{array}$ & \\
\hline marketing & 348 & $\begin{array}{l}\text { Problems related with } \\
\text { marketing }\end{array}$ & $\begin{array}{l}\text { Ordinal } \\
(1=\text { strongly agree, } 5=\text { strongly disagree })\end{array}$ & \\
\hline entage & 348 & Age of enterprises & ordinal $(1=2-5,2=6-10,3>10)$ & \\
\hline avprofit & 348 & Annual average profit & Scale & 9825.489 \\
\hline investment & 348 & Investment of the owners & Scale & 45275.86 \\
\hline
\end{tabular}

